\title{
Mindbombs of right and wrong: cycles of contention in the activist campaign to stop Canada's seal hunt
}

\author{
Peter Dauvergne and Kate J. Neville
}

Version Post-Print/Accepted Manuscript

Citation Dauvergne, P., \& Neville, K.J. 2011. Mindbombs of right and wrong:

(published version) cycles of contention in the activist campaign to stop Canada's seal hunt. Environmental Politics, 20(2): 192-209.

Publisher's Statement

"This is an Accepted Manuscript of an article published by Taylor \& Francis in Environmental Politics on March 17, 2011, available online: http://www.tandfonline.com/10.1080/09644016.2011.551024."

How to cite TSpace items

Always cite the published version, so the author(s) will receive recognition through services that track citation counts, e.g. Scopus. If you need to cite the page number of the TSpace version (original manuscript or accepted manuscript) because you cannot access the published version, then cite the TSpace version in addition to the published version using the permanent URI (handle) found on the record page. 


\title{
Mindbombs of Right and Wrong: Cycles of Contention in the Activist Campaign to Stop Canada's Seal Hunt
}

\author{
Peter Dauvergne and Kate J. Neville* \\ Liu Institute for Global Issues, University of British Columbia, Vancouver, Canada
}

Abstract

\begin{abstract}
Activists use emotional language and images - what Greenpeace co-founder Bob Hunter coined 'mindbombs' - to convince people that some actions are wrong, morally and environmentally. For over 50 years anti-sealing activists, for example, have employed mindbombs to transform seal pups into babies and seal hunters into barbarians. Although 'image politics' contributed to the decline of the Canadian sealing industry in the 1980s, its effectiveness has been - and continues to be - rocky, particularly as pro-sealing voices counter with competing claims of cultural rights, traditional livelihoods, and sustainable use. Drawing on Tilly and Tarrow's 'cycles of contention' framework, it is found that controlling and predicting the global uptake of messaging is becoming harder as activists operate in an increasingly crowded discursive landscape, as campaigners and countercampaigners articulate scientific and moral frames that resonate differently across changing social and cultural contexts, and in light of globalising markets, transnational networks, and changing media.
\end{abstract}

Keywords: seal hunt; cycles of contention; mindbombs; image politics; environmental activism; globalisation

\section{Introduction}

Since the 1960s activists have been conducting campaigns to blast 'global consciousness' with emotional language and images - what Bob Hunter, a Greenpeace founder, imaginatively coined as 'mindbombs'. The goal is grand and simple: to convince people that some practices and choices are wrong, morally and environmentally. Over time activists have helped to transform how many people think about other species, turning whales into majestic beings, dolphins into friendly playmates, and seals into cuddly babies, to name just three.

The successes and failures of mindbomb campaigns - what some describe more broadly as 'image politics' (DeLuca 1999) - provide insight into the changing nature of environmental activism in light of globalising markets, transnational networks, and competing discourses of conservation, animal rights, cultural survival, and traditional livelihoods. We examine the 'cycles of contention' (Tilly and Tarrow 2006) in campaigns surrounding the Canadian seal hunt, and argue that fluctuations in seal markets (and thus the size and nature of the hunt) reflect, in part, a tension between how supporters and opponents of sealing frame debates. We further argue that competing imagistic and discursive framings of the hunt reflect a dynamic process of political contention by groups with diverse perspectives. This suggests a rocky future for the sealing industry as campaigners and counter-campaigners articulate scientific and moral frames that resonate differently across changing social and cultural contexts. It also suggests a similar future

*Corresponding author: Email: peter.dauvergne@ubc.ca 
for more general debates over the ethics and sustainability of the commercial use of wild animals and the broader struggles between advocates of strict preservation and proponents of 'sustainable use'. The discursive and mindbomb battles over sealing have been echoed, for instance, in recent meetings of the Convention on International Trade in Endangered Species of Wild Fauna and Flora (CITES), such as the one in 2010 in Qatar where stuffed toy polar bears and elephants were competing with videos about indigenous and community livelihoods (co-author Neville was in attendance).

We focus on two main questions. First, why, despite the effectiveness of early antisealing campaigns, is the current movement struggling? Second, what do these struggles suggest for the future of this campaign and the seal hunt? The answers point to a confluence of factors, centring on changes within four domains: anti-sealing NGOs and environmental movements; pro-sealing countermovement groups; media and public space; and policy audiences and consumers. Looking into these domains reveals a contentious politics of competing claims, and suggests, more generally, that activists and their challengers operate in an increasingly crowded, complicated, and unpredictable landscape.

Initially, a mindbomb strategy appeared to achieve outright victory for activists when in 1987 Canada officially closed its commercial hunt for 'whitecoats' (6-12 day old harp seal pups) off southeastern Labrador and northeastern Newfoundland (known colloquially as 'the Front') and in the Gulf of St. Lawrence (called 'the Gulf'). In the 1970s and 1980s, demand and prices for seal furs fell as activists dropped images into the media of hardy fishermen bashing in the skulls of baby whitecoats with puppy-dog eyes, and raised millions of dollars to fill conventions with snow-white balloons and hand out soft toys for children to snuggle. By 1987, with prices low, and with anti-sealing activists organising a boycott of Canadian fish products, many of the earlier supporters of sealing were ready - even eager - to concede defeat.

This was not, however, a lasting victory. In the mid-1990s, the Canadian government quietly began to subsidise a 'new' commercial hunt for 'mature' harp seals: not for the 6-12 day old whitecoats, which the government continues to protect, but mainly for 'ragged jackets' (molting pups, 2-4 weeks old) and 'beater' seals (2-12 weeks old) with silvery coats and black spots. Before long, hunters were landing hundreds of thousands of harp seals, with the total number breaking the 300,000 mark in 2002, making it the biggest hunt since the 1960s. Hunters continued to land hundreds of thousands of seals each year after 2002, until 2009 and 2010, when Canadian sealers took only a fraction of the allowable quotas. Pelt prices plummeted near the end of the decade, in large part owing to the global financial crisis of 2007-09. But activist messaging to consumers and uncertainty in European markets in response to a proposed EU ban on all seal product imports (passed as a regulation in September 2009 to take effect in August 2010) also dampened both consumer demand and the enthusiasm of potential importers. While poor ice conditions, particularly in the Gulf, contributed to a low 2010 harvest, sealing associations had already been expecting a small hunt because of the market uncertainty: a result, in part, of the latest cycle of contention between opponents and supporters of sealing.

\section{Cycles of Contention: A Framework for Understanding Activism and Responses}

In contentious politics, actors' claims affect the interests of others, and lead to 'coordinated efforts on behalf of shared interests or programs, in which governments are involved as targets, initiators of claims, or third parties' (Tilly and Tarrow 2006, p. 4). For Tarrow (1998), social actors engage in contentious politics by taking advantage of political opportunities to use - and 
provide opportunities for others to use - 'repertoires' of collective action in widening 'cycles of contention'. Further, social movements challenge opponents through sequences of collective action backed by dense social networks and culturally-relevant action-oriented symbols for common purposes; these movements tend to engender dynamic and fluctuating countermovements (Tilly and Tarrow 2006, p. 21). Used as framing devices by both movements and countermovements, mindbombs are, in DeLuca's (1999) terms, image events that transform the audience's worldview; similarly, for Bondaroff (2008, quoting Stephen Dale), they are 'influential, sometimes archetypal images that can cut through the hypnotic drone of the day to day babbling'.

Environmental activism can helpfully be understood through the lens of these cycles of contention. In this model, political contention can be seen as a series of episodes of claimmaking and response, rather than as a continuous chain of action. Consequently, an 'event history', where key episodes are demarcated on a timeline (Tilly and Tarrow 2006, p. 39), can be used to identify changes in the strategies within the movement and countermovement, and can provide insight into why certain attempts at framing and claim-making transform worldviews, while others are ineffective or short-lived.

In the case of the current anti-sealing campaign a combination of factors seems to be limiting the influence of mindbomb activism. We need, as Carragee and Roefs (2004) advise, to analyse a range of actors involved in issue framing and uptake to assess their relative power in influencing discourse and outcomes. Beyond the 'central claimants' (Tilly 2004) of the antisealing campaigns, we must consider efforts of governments, sealers, and Inuit communities in countermovements, along with public and consumer responses. For this reason, our assessment of the varying effectiveness of anti-sealing efforts considers activism as a dynamic process, involving both changing movement and countermovement organisation and the competing discourses over time (as DeLuca 1999 recommends). We begin with the history of the seal hunt and early campaigns: essential background to understand the changing frames for the hunt over the last half-century.

\section{The Anti-Sealing Movement - History of the Hunt and Early Activist Campaigns}

Activists launched anti-sealing mindbombs in the 1960s and 1970s into a media environment where these approaches were still novel. Waging campaigns on moral grounds, activists sent graphic images across media outlets; at the time, responses defending the hunt were fragmented, as agencies within the Canadian government were divided, while the sealing industry was small and uncoordinated (consisting largely of fishermen from poor communities in isolated regions of Canada), and Inuit and First Nations communities were only beginning to assert traditional rights and claims. Many Newfoundlanders were angry as the activists turned images of their heroes and hunters into cowards and killers, but found it difficult to counter the portrayals of a 'brutal' and 'inhumane' hunt.

\section{Sealing from 1800 to 1960}

In Canada, the Atlantic sealing industry peaked in the 19th century. The primary market was the United Kingdom (UK), mostly for oil and, to a lesser extent, sealskins. Despite a lack of markets for whitecoat furs (because of processing limitations for their lanugo fur), demand for whitecoats was nonetheless high because of their high oil content and the relative ease of 'harvesting' the 
pups. Since whitecoats tend to lie motionless and undefended by adults for the first week of life, sealers could quickly kill the pups with a 'gaff' (a 3-foot wooden club with a hook).

Between 1825 and 1860, there were 11 years in which hunters landed more than 500,000 seals, with the all-time high of 740,000 seals set in 1832 (Fisheries and Oceans Canada 2004, Horwood 1960, p. 39). The actual number of seals killed during the sailing and steamships eras, however, was far higher than the landed catch, as beaters and adults swam away or sank before hunters, after shooting them, could gaff them out; one report of this 'struck-and-lost' rate estimated that during the sailing era as many as 20 adult seals were lost for every one caught (Kean 1935, p. 131). The large hunts caused the population of harp seals to fall in the second half of the 1800s. Owing to these smaller herds, by the late 1800s landing a total catch of over 300,000 was a good year, even as wooden steamships allowed smaller crews to conduct more efficient hunts.

In the first half of the 20th century technological advances in production processes (like hydrogenation) and in ship design (like steel steamers) brought new efficiencies and markets to the industry. Still, the commercial decline of Newfoundland's sealing industry continued as World Wars I and II and the Great Depression reduced the availability of ships, men, and money (sealing steamers, for example, went into military service). With a much smaller hunt at the Front and in the Gulf, the population of seals seemed to stabilise in the 1930s and even rejuvenate slightly by the end of World War II.

This was a short-lived recovery, however, as the population of northwest Atlantic harp seals again went into decline in the 1950s when Norwegian and Nova Scotian vessels began to replace Newfoundland ones, bringing new interests, sturdier boats, and better equipment, including refrigeration, radar, and helicopters. The Norwegians also increased the value of whitecoat pelts, as they made advances in preventing the lanugo fur from falling out of dressed whitecoat furs. The annual catch began to climb through the early 1950s, but tailed off again in the latter half of the decade as stocks fell. Sealers were taking more mature seals to maintain such large catches. Also, the Norwegians, not bound by Canadian regulations, were hunting after the official end of Canada's season: a date set to protect adult breeders during the northern migration in May (and thus protect the whitecoat population for the next season). With these strategies, and more efficient technologies, hunters managed to land on average 285,000 seals from 1961-1965 (see Table 1).

Table 1: Average Number of Harp Seals Landed per Year

\begin{tabular}{|l|l|l|l|l|l|}
\hline & $\mathbf{1 9 1 2 - 1 9 4 0}$ & $\mathbf{1 9 5 1 - 1 9 5 5}$ & $\mathbf{1 9 5 6 - 1 9 6 0}$ & $\mathbf{1 9 6 1 - 1 9 6 5}$ & $\mathbf{1 9 6 6 - 1 9 7 0}$ \\
\hline Harp Seals/Year & 159000 & 330000 & 300000 & 285000 & 280000 \\
\hline
\end{tabular}

By then, more and more individuals, government scientists, and groups like the Canadian Audubon Society were starting to call for much stricter controls to ensure the seals' survival. Animal rights activists were joining forces with environmentalists to call for an end to the 200year-old commercial hunt.

\section{Opposing the Seal Hunt: The 1960s and 1970s}

Before the late 1950s, few outside of Eastern Canada had heard of the seal hunt. Some of the first rumblings about its 'inhumanity' came after Harry Lillie, a former sealing ship medical officer, sent film of the 1955 hunt to humane societies. The uproar, though, came a few years later, when 
a 1964 documentary by Artek Films, which seemed to show a landsman skinning a seal alive, reached a global audience. Thousands of letters flooded Canada's Ministry of Fisheries following the Artek Film. In October 1964, the Canadian government introduced new regulations, requiring sealers to obtain licenses, restricting the Gulf and Front hunting seasons to seven weeks, prohibiting the skinning of live seals, and requiring clubs to be big enough to kill quickly. Also, overnight panning was banned (except during storms), as was the killing of adult seals in breeding patches. Further, the regulations set a quota of 50,000 seal pups for the Gulf, effectively ending Norwegian sealing there. Despite these new rules, the emerging anti-sealing movement saw the government's response as utterly inadequate, as from 1966-1970 the average annual catch only declined slightly from previous years (see Table 1). Introducing quotas shifted the focus of hunters somewhat from seals-for-leather to seals-for-furs (preferentially taking whitecoats over ragged jackets), especially with fur prices rising in the 1960s. Consequently, some activists, notably Brian Davies of the New Brunswick Society for the Prevention of Cruelty to Animals (SPCA), began to call for an end to seal hunting.

From this point onwards, anti-sealing activists used the mindbomb strategy in earnest. In 1968 and 1969, Davies led observers, including journalists from London's Daily Mirror and the Paris-Match, to the Gulf hunt (Davies 1989 provides a personal account). Prices for sealskins tumbled from 1965 to 1968 , with media portraits of an inhumane hunt contributing to market turmoil. This campaign gained focus after Davies left the SPCA and founded the International Fund for Animal Welfare (IFAW) in 1969 with a mandate to end the hunt. Soon, cuddly whitecoats were everywhere: on posters, in pamphlets, as stuffed animals. In what Lynge (1992, p. 29) describes as a 'brilliant' (though problematic) turn of rhetoric, activists labelled seal pups 'babies', and told stories of these 'babies' butchered in 'nurseries;' to the horror of many, they also showed videos of weeping pups (fluid to protect their corneas runs out of tear ducts) seemingly skinned alive (like chickens, seals have a swimming reflex that can continue after death).

These mindbombs were effective in provoking policy change. Through the late 1960s and the 1970s, the Canadian government imposed increasingly strict guidelines for seal hunting. For the 1967 hunt, the gaff (sometimes used to hook into live seals) was banned, and inspectors were given the power to revoke sealing licenses for inhumane hunting. For the international waters of the Front, domestic measures alone were insufficient to stabilise the seal population: international measures were taken for the 1968 hunt, with the Front opening date changed from 12 March to 22 March to lessen the pressure on the whitecoats, and the closing date changed, too - from 30 April to 25 April - to reduce the number of breeders caught. At the Gulf, the government banned the whitecoat hunt in 1970 and no longer allowed vessels over 65 feet in 1972. These decisions in effect switched the large vessel hunt entirely to the Front, while reserving the Gulf for 'landsmen' (sealers hunting from shore, inshore ice, and small boats). The International Commission for the Northwest Atlantic Fisheries (ICNAF), at Canada's urging, also acted to protect the Front in the first half of the 1970s. By 1976 the quota for harp seals at the Front was down to 127,000 (52,333 for Canadian vessels, 44,667 for Norwegian vessels and 30,000 for landsmen).

The life of a sealer in the 19th and first half of the 20th centuries was dangerous - over a thousand men were lost during violent storms and on the treacherous ice floes. In Newfoundland, these sealers - who locals called 'swilers' - were considered heroes, family men, and brave sons. However, activists charged that the hunt had changed in light of technological developments: Brian Davies took American airline stewardesses by helicopter to the 1976 hunt - in part to try to 
debunk the 'myth' of a dangerous hunt. That year Greenpeace joined the protest, arriving in Newfoundland in a storm of publicity after announcing a plan to spray whitecoats with a nontoxic green dye to destroy much of the commercial value of the pelts. Media outlets - from NBC News to Der Stern to the Canadian Broadcasting Corporation - pounced on the spectacle of young idealists challenging hardened Newfoundlanders.

Government measures to try to halt the decline of northwest Atlantic harp seals did little to mollify the strengthening campaign against the hunt. By the beginning of the 1970s, the population was below 2 million, a drop of well over a million from 1950, and far less than during the heyday of the seal hunt in the mid-1800s. The trend, according to Greenpeace activists, was indisputable and ominous: a seal population of 20-30 million in the $1700 \mathrm{~s}$, falling to 10 million by 1900,3 million by $1950,1.5$ million by the early 1970s, and 1 million by the mid-1970s (Weyler 2004, pp. 352-363, footnote 6, p. 601; also see Allen 1979 and Harter 2002 for a more critical accounts). Greenpeace and IFAW returned to the hunt in the spring of 1977. That year the activists pulled off a publicity coup by flying in French actress Brigitte Bardot - and a photo of her cuddling a whitecoat was splashed on the cover of Paris Match.

During this time the Canadian and Newfoundland governments attempted to coordinate a countermovement, opposing activist messaging with the language of 'scientific management' and of hardworking sealers 'harvesting' a 'traditional product'. But by this stage the activists were winning the 'word-battle map': the 'socially acceptable' discourse for describing and interpreting the hunt (Lee 1988, pp. 23-25). More and more consumers began to see the 'hunt' as a senseless slaughter of endangered mammals: 'sealers' were now 'killers', seals now 'victims'. Moreover, a lack of coordination within the Canadian government hindered efforts to counter the activists' messages, with the Department of Fisheries and Oceans seeking to maintain a sustainable hunt and the Department of Foreign Affairs and International Trade more focused on mitigating the effects of the controversy on Canada's external reputation and other commercial interests (Barry 2005).

Realising the campaign was strengthening, the Canadian government did start to take stronger measures against activists, convicting Davies in 1977, for example, of violating sealing regulations for bringing his helicopter too close to the hunt: a conviction that prevented him from returning the following year. Canada also tried to block other protestors from returning in 1978 by passing an Order-in-Council that made it illegal to go on the whelping ice without a permit. In a barefaced move, the initial Order stipulated an application deadline of a week before the law was passed. Greenpeace lawyers were able to overturn this impossible rule. But the fight for the handful of permits was bitter. Greenpeace members Rex Weyler and Patrick Moore were arrested and charged with 'loitering' in a Department of Fisheries office for trying to obtain a permit. Eventually, Moore and Weyler did make it to the ice, although Moore was again arrested and charged with violating the Seal Protection Act for interfering with the hunt. His crime: holding a startled whitecoat (Weyler 2004, pp. 493-501).

Such tactics did little to stem the rising tide of activism: arguably, it even inflamed media interest and consumer anger outside of Canada, with activists using these actions as 'focusing events' (Birkland 2005). Activists continued to lobby politicians and gain media coverage in Europe - especially in the UK. Seal pelt prices, which had been slowly rising after the fall in prices in the second half of the 1960s, again began to fall in the second half of the 1970s as the campaign left whitecoat markets skittish (although, a consumer shift to longer-haired animals also partly explains lower prices for seal pelts). Meanwhile, IFAW fundraising went up, reaching close to C\$1.3 million in 1977, and other groups, like the New York City-based Fund for 
Animals and Greenpeace, continued to disrupt the hunt through 1978 and 1979 using tactics like the spraying of whitecoats with dye. Apart from revoking permits, the Canadian government could do little in response.

During the 1970s sealers took far fewer harp seals than in previous decades: partly because of the protests and resulting market instabilities; partly because of quotas; and partly because of the comparatively small herds. The harvest fell to about 230,000 in 1971 (down 50,000 from the 1966-70 average), then dropped below 175,000 in each year for the rest of the 1970s (Fisheries and Oceans Canada 2003, p. 6). In an adaptive move to frame new conditions within the movement's central message, environmental activists dismissed the lower harvests as a sign of a species on the brink of extinction, not better management. As Snow et al. (1986) explain, the effectiveness of protest cycles can be attributed in part to the "presence or absence of a potent innovative master frame and/or the differential ability of SMOs [social movement organisations] to successfully exploit and elaborate the anchoring frame to its fullest'. Animal rights activists, too, remained upset that whitecoats still comprised nearly $80 \%$ of the catch. In 1977, when Canada adopted a 200-mile fishing zone and became solely responsible for the Front, the federal government tried to focus the hunt on whitecoats and immatures by, for example, allowing adults to comprise only $5 \%$ of the total catch of large vessels (Candow 1989, p. 124). By the beginning of the 1980s, the anti-sealing campaign was growing even stronger, especially in Europe.

\section{Victory: Closing the Hunt in the 1980s}

Greenpeace continued its direct action campaign, sailing the Rainbow Warrior to the Front in 1981 and to the Gulf in 1982 to spray green dye on whitecoats. IFAW, meanwhile, took out fullpage ads in European newspapers asking readers to write to European Parliament members and call for a ban on the import of whitecoats and 'bluebacks' (nursing hood seals). By the early 1980s at least three million letters and postcards - and perhaps as many as five million - had deluged the European Parliament (Royal Commission on Seals and the Sealing Industry in Canada 1986, pp. 68-69).

By March 1982 the Canadian government was scrambling to convince members of the European Parliament to reject the proposed import ban. The Canadian delegation faced a throng of protestors waving petitions and baby-white balloons with teary eyes. Again, the countermovement's messaging was weak: Canada's response - which included handing out buttons saying, SAVE OUR COD, EAT A SEAL - was an utter failure. The vote in the European Parliament, though non-binding, was decisive: 160 to 10 to ban whitecoat and bluecoat seal imports. It was a clear sign Canada was losing the battle for Europe's markets, which accounted for three-quarters of Canadian seal pelt exports; in November 1982 the European Parliament passed a temporary import ban, effective 1 March 1983 (Joyce 1982, pp. 23-24, Goar 1982, pp. 23-25, Candow 1989, p. 136). The ban devastated Canada's sealing industry. The average price of a seal pelt in 1983 fell to $\mathrm{C} \$ 13$ : half of what it was the previous year. Only three vessels went sealing in the spring of 1983 and in the end sealers only landed 30,000 pelts.

In the meantime, IFAW pressed on. In late 1983, it began to lobby consumers and supermarkets to boycott all Canadian fish products until Canada closed the hunt, distributing over four million pre-printed postcards with this message to consumers in Britain. Results were swift. In early 1984 Britain's biggest supermarket chain, Tesco, declared it would no longer purchase Canadian fish products until the hunt ended, with Safeway quickly following suit. 
IFAW then took its boycott campaign to the United States - which at that time accounted for $80 \%$ of Canada's fish exports - printing five million boycott postcards for American consumers (targeting chains such as MacDonald's and Burger King).

This threat to Canadian fish exports triggered calls within Canada to concede defeat and close the whitecoat hunt; the successes of the anti-sealing movement were now fragmenting the small countermovement. The sealing industry wielded comparatively little influence on federal politics. Even within Newfoundland, this industry was relatively small and, although most Newfoundlanders supported sealing, many worried about the economic consequences of a boycott of Canadian fish products. The landsmen, meanwhile, broke ranks with the sealing fleets and in 1982 formed the Canadian Sealers' Association. This association called for a moratorium on the hunting of whitecoats, arguing this would diffuse the worldwide protest without drastically harming the income of landsmen, since most hunted beaters, 'bedlamers' (about 1-4 years of age), and adults.

The Canadian government tried to stand its ground. The Fisheries Department continued to challenge the image of a slaughter of 'babies', for example, making the following analogy in a Toronto Star article in February 1984: 'A ragged jacket is like a 20-year old leaving home, and by the time it reaches a year old, it's been through a couple of jobs and a divorce' (quoted in Lee 1988, p. 24). They also undermined the credibility of organisers of the boycott of Canadian fish products, calling them 'blackmailers', 'liars', and 'fascists' (New York Times article, quoted in Anon 1984, p. 2). However, these efforts were unable to unsettle the increasingly dominant frame forwarded by anti-sealing activists. Although still technically legal in 1984, no large vessels went to the ice in 1984, and for the first time in centuries, the hunt was left to landsmen. This was the case in 1985 and 1986, too, as Europe renewed the import ban. Two commercial ships did go to the ice in March 1987 to hunt beaters and adult seals with rifles - but, primarily because of heavy ice, they only landed about 3,100 pelts (Candow 1989, p. 189).

By this time, the population of northwest Atlantic harp seals was rebounding - with over 2 million birthing about 500,000 whitecoats each year by the mid-1980s (Fisheries and Oceans Canada 2004). Harp seals were certainly not under threat of extinction or endangerment. Nevertheless, at the end of 1987 the Canadian government banned the hunting of whitecoats and bluebacks. The government also prohibited the hunting of other seals from large offshore vessels (over 65 feet or 19.8 metres in length). This was done, Newfoundland Member of Parliament John Crosbie explained on CBC television in December 1987, partly to end the campaign to boycott Canadian fish products. It was still legal for landsmen to shoot seals from small boats, and the annual quota of 186,000, first put in place in 1983, was maintained. However, landsmen did not have the capacity to reach this quota and along with low prices and weak consumer demand, the Canadian seal hunt from 1983 to 1995 averaged only 51,000 harp seals per year. The Sea Shepherd Conservation Society, IFAW, and Greenpeace celebrated this 'closure' as a triumph of decency and ecology over unnecessary consumption. Davies (1989, p. 220) called it 'a victory for Canada'. The war was not over, however, and a decade later pro-sealing forces were back.

\section{The Return of the Commercial Hunt and Changing Effectiveness of the Anti-Sealing Movement}

By the mid-1990s the population of northwest Atlantic harp seals was over five million - still well below the 20-30 million in the 1700s, but above the 3 million or so in the early 1950 s and 
the 1-2 million in the 1970s. The closure of the hunt had caused economic hardship in some east coast fishing and Inuit communities. Lost sealing revenue had reduced the income of the Inuit in Labrador, for example, by one-third. The Inuit were, in the words of John Amagualuk of the Tunngavik Federation of Nunavut, 'innocent bystanders' caught in a war where the activists, media, and consumers failed to distinguish between the Inuit hunting of adult seals from the commercial whitecoat hunt (quoted in Dale 1996, p. 91; also see Lynge 1992). The Canadian and Newfoundland governments, looking for ways to support out-of-work fishermen following the collapse of cod stocks, kept in place the ban on hunting 6-12 day old whitecoats, but took steps to expand the fleet of small vessels hunting so-called 'mature' seals. The quota was raised for beater seals and millions of dollars of indirect and direct subsidies were given to fishermen and seal processing facilities.

At the same time, the government and sealing industry worked to expand markets for seals. The Canadian Seal Industry Development Council, for example, went on tour in the late 1990s to lobby the fur industry. This was - and remains - a formidable challenge, as the 1972 Marine Mammal Protection Act prevents sales of beater pelts in the US market, which accounts for $80 \%$ of Canadian fur exports. Nevertheless, by the late 1990s seal furs were coming back into fashion elsewhere, partly on the tide of a resurging world market for furs. A new episode had begun in the contention over the hunt.

Supermodels, who a decade earlier were saying, 'I'd rather go naked than wear fur', began to arrive at fashion shows draped in real furs. In 2002, furs were the 'best-performing luxury item' of the year, with sales rising more than $10 \%$ worldwide and the average age of customers falling as furs became 'trendy'. Even in the UK, one of the world's most hostile fur markets, retail sales jumped by $35 \%$ in 2002 . Some young customers were telling marketers they were 'tired of being preached at' and felt a sense of rebellion with the purchase (quoted in Friedman 2003, p. 5). With government support and strengthening markets, the harp seal catch for 1996 jumped to over 240,000, rising again in 1998 to over 280,000, before falling slightly in 1999 to a little below 245,000. The following year low pelt prices and poor ice conditions for hunting caused it to drop to just 91,600. This was a temporary setback, however, and hunters landed over 226,000 harp pelts in 2001. By then, the sealing industry was back on its feet and the Canadian government was able to end direct subsidies. The following year the total harp seal catch broke the 300,000 mark $(312,000)$ for the first time since the 1960s.

The resurgence of a commercial seal hunt surprised many activists. New regulations did little to appease them, and soon groups like Greenpeace and IFAW, along with more than 50 others, were again campaigning to close the hunt. On the anti-sealing side, the language and tactics of renewed opposition were not much different than in the 1970s and 1980s, with stunts for the media, videos, petitions, and efforts to disrupt markets. The US Humane Society called it 'the largest commercial slaughter of marine mammals on the planet'. IFAW charged the 'annual baby seal hunt' is still 'unacceptably cruel;' the Green Party of Canada agreed, seeing it as 'extreme brutality;' and the Sea Shepherd Conservation Society talked about the Canadian government's 'kill quota' and its 'death sentence' for millions of baby harp seals. The celebrities - from actor Martin Sheen to musician Paul McCartney - were back, too. Sheen, speaking in his West Wing presidential voice on the Sea Shepherd Conservation Society website, called for an end to the 'annual ritual of blood and slaughter of the innocents'. In a March 2006 press release receiving Canada-wide media coverage, McCartney called the hunt 'heartbreaking', and 'a stain on the character of the Canadian people'. 
Yet anti-sealing activists found themselves making little headway influencing consumers or governments. The annual harp seal catch was higher than it had been in the 1960s, 1970s, and 1980s. The major players of the past - in particular Greenpeace and IFAW - had become larger, more complex, and less confrontational than in the 1970s and 1980s, and opposing the hunt was no longer quite so central to their mandates. The history of IFAW is revealing. There were just seven staff when Brian Davies moved the headquarters in 1979 from Fredericton (New Brunswick, Canada) to Cape Cod (Massachusetts, USA). By the time Frederick O'Regan took over from Davies as IFAW president in 1997, the Cape Cod office had over 70 employees. Today, the organisation involves a Cape Cod-based team of over 100 scientists, administrators, and specialists with an annual payroll of more than US\$3 million, and, worldwide, over 200 employees and 13 offices. And it now has numerous campaigns, for whales, elephants, seals, cats, and dogs, among others (Murphy 2004, www.ifaw.org).

Splits occurred across activist organisations too, particularly among those more concerned with ecosystem conservation and endangered species than with animal rights; notably, the WWF does not oppose what it now sees as a sustainable and reasonably humane hunt. Coordinating the anti-sealing campaign among a growing number of organisations was also becoming more difficult. The so-called Unified Opposition against the hunt, for instance, is united on the mission of stopping the seal hunt but divided on what tactics are best to achieve this goal. Some members - most notably Greenpeace and IFAW - do not support the 'Canadian Seafood Boycott', a campaign, similar to the 1983 boycott, launched in 2005 by a coalition of more than 60 other activist groups (including People for the Ethical Treatment of Animals, the Sea Shepherd Conservation Society, and the Humane Society of the United States) to press stores and restaurants to stop selling Canadian seafood until the seal hunt ends. It is difficult to present a coherent front on such a boycott when the anti-sealing groups are not aligned on the approach.

Coordination is not the only challenge for today's activists; the audience for campaigns is also more diverse and sceptical. The goal of the seafood boycott is straightforward: "to directly cost those who kill the seals 50 to 100 times more than what they earn from the commercial seal hunt' (see 'Boycott Canadian Seafood', at www.sealhunt.ca). However, this campaign assumes 'those who kill the seals' includes the Canadian seafood industry, even though only a small portion has direct ties to commercial sealing. So far the coalition has only been able to convince a handful of buyers of this connection, and those joining the boycott - like Wild Oats Markets and Kimpton Hotels and Restaurants - comprise only a tiny portion of the over-C $\$ 3$ billion Canadian seafood industry (70-75\% of which is earned from exports to the United States). This limited uptake by companies indicates that the message has not been compelling to most consumers. Over the last two decades the pro-sealing countermovement has been changing, too, emerging as a far more powerful counterforce to those who call for an end to commercial sealing.

\section{Countermovement: Return of the commercial hunt in the 1990s}

Activists now face a more coordinated and compelling counter-campaign. To preempt animal rights protests, Fisheries and Oceans Canada (2003, p. 1) modified its policies to promote a 'quick and humane dispatch' of beater and adult seals, including requirements for federal apprenticeships for sealers, and a 2003 amendment to the Marine Mammal Regulations that requires additional steps for sealers to confirm brain death prior to skinning. The government 
also claims that seals are no longer under threat - some officials went even further in the mid1990s, justifying a higher allowable seal catch to protect the crashing cod stocks off Newfoundland's Grand Bank from the 'exploding' population of harp seals. The science to back this was questionable, and today Fisheries and Oceans Canada no longer makes this claim. Still, in 1995 this was an influential image: 'There is only one major player fishing that stock', Canadian Fisheries Minister Brian Tobin explained. 'And his first name is harp, and his second name is seal' (quoted in Lavigne 1995, p. 11). Tobin's estimate on CBC television that harp seals were consuming one billion Atlantic cod annually was widely cited even though no authoritative scientific analysis backed him. Such claims have played well, however, into the government's language of 'sustainable harvests', protecting 'traditional' livelihoods, and 'managing' the oceans to ensure balance among species. 'It's not just about revenue', Fisheries Minister Loyola Hearn said in 2006. 'It's about sustainability of a herd' (quoted in Armstrong 2006, p. A8). This description of a growing seal population 'out of balance' remains a powerful frame for the public, especially when aligned with messages of cultural rights, livelihoods, and sustainable resource use.

During this episode of contention, the Canadian government has been managing its media messages more adroitly, with public relations teams countering the activists with images of saltof-the-earth fishermen, statistics indicating an abundance of seals, and the language of sustainable and humane management. Anti-sealing campaigners consequently now face more public disagreement on both their morality and conservation claims, with images of thriving seal populations and traditional Inuit rituals now competing with ones of cuddly, endangered seals and brutish, cold-blooded hunters.

\section{Uncertain Future}

Image politics depends not only on the framing efforts of the primary contenders but also on the dissemination and uptake of the messages. The increase in the number of NGOs worldwide makes it much harder for activists to use the media to change the 'consciousness' of consumers. A more diffuse anti-sealing movement increases the potential for contradictory messages and for one group to make a mistake that discredits the movement. Importantly, the power of graphic images has also weakened as these become more familiar. Some environmental organisations have been pushed into a process of radicalisation because of a need to produce increasingly strong images (Bondaroff 2008): the use of mindbombs tends to diminish their effectiveness over time, creating a cycle of ever-more startling images with ever-decreasing effectiveness. More activists are also competing for each minute-or-so of daily protest-fame, making it harder and harder to dream up tactics that are novel news items. At the same time consumers and public audiences are becoming more jaded. As mindbombs from the anti-sealing movement become more familiar and dovetail with graphic images from other animal rights and environmental campaigns, the power of these images to affect public sentiment decreases even further. Moreover, the campaigns can backfire as some consumers - even in Europe - are weary of what they see as a preachy tone among anti-sealing activists.

Beyond the desensitisation of European and North American consumers, another factor impeding activists is the globalisation of markets for seal furs. Activists continue to gain ground in Europe: for example, in 2007 Belgium, Italy, and Luxembourg banned all seal-product imports, not just whitecoats, and the European Parliament debated a call in March 2007 for a full ban. This was rejected; but the European Commission agreed to investigate further. The 
following year the European Commission proposed restricting the import of seal products (with some exemptions for Inuit hunters) unless exporters could prove the hunt was not cruel, and that seals were spared 'avoidable' pain or distress. The purpose was made clear by Stavros Dimas, European Commissioner for the Environment, at a news conference in July 2008: 'Seal products coming from countries which practice cruel hunting methods must not be allowed to enter the EU' (quoted in Moore 2008, A7). In late 2008 Canada modified its Marine Mammal Regulations to strengthen its rules for 'humane' sealing and improve its surveillance of hunters: apparently, this was partly designed to address EU concerns and avoid market disruptions in 2009. Nonetheless, in 2009 a regulation was passed to ban all seal product imports across the EU by 2010.

Although trade statistics on seal products are difficult to track, given that only 'relatively unrefined products can be identified in Canada's export statistics' (Fisheries and Oceans Canada 2010), recent estimates suggest that EU countries are no longer core markets for Canadian seal pelts. In recent years Norway has been the primary buyer of raw seal pelts, while China and Russia have accounted for $90 \%$ of imports of processed harp seal furs. Canadian exporter Dion Dakins of Newfoundland's Barry Group of Companies sums up these trends: 'Russia is the No. 1 customer, with China coming on with insatiable demand' (quoted in Armstrong 2006, p. A3). Canadian Fisheries Minister Gail Shea aimed to encourage this growth in Chinese markets, with a trip to China in January 2010 focused on promoting seal products. Recent media coverage perpetuates the message that emotional appeals will be less successful in these emerging markets, with Clark (2010) editorialising that in China 'a tradition of eating a wide variety of animals, including dogs, makes it relatively immune to emotional appeals to spare cute seals'. As Dakins dryly explains: 'they couldn't care less about Paul McCartney' (quoted in Armstrong 2006, p. A3).

The immunity of these new markets to transnational activist campaigns, however, is by no means certain: in 2009, Russia banned the domestic hunting of seals under a year old, with the Russian Minister of Natural Resources, Yury Trutnyev, quoted as saying: 'This bloody hunting is from now on banned in our country, as in most developed countries. This is an important measure to preserve Russia's biodiversity' (McKiernan 2009). This public justification involving identity claims (Russia as a developed country) and conservation values (preserving biodiversity) indicates that the potential power of anti-sealing messages in these new and emerging markets remains an open question (see Epstein 2008 for a discussion of identity claims in anti-whaling debates). The EU ban, moreover, is not certain to stay in place as the Canadian and Norwegian governments are challenging it at the World Trade Organization while a coalition of Canadian and Greenlandic Inuit groups is doing the same at the European General Court.

The now largely-cohesive Canadian government continues to press the pro-sealing agenda through symbolic actions on national and international stages. In February 2010, the government hosted the G7 Finance Summit in Iqaluit in conference rooms with seal-covered seats, with delegations greeted by seal-clad locals and fed seal meat; in March 2010, seal was on the menu at the parliamentary restaurant in Ottawa. Even with weak demand for seal products (with pelt prices bottoming out at $\mathrm{C} \$ 14$ in 2009 and only averaging around $\mathrm{C} \$ 23$ in the spring of 2010), and despite many buyers having a backlog of pelts, the government nonetheless increased the harp seal quota for the 2010 hunt by 50,000 (for a total allowable catch of 330,000 for harp seals), stressing that the harp seal population was continuing to rise (now at 6.9 million) (Vaughan 2010). The uncertainties in the future of the environmental conditions, hunt, regulations, and seal product markets reflect the difficulty in predicting which messages and 
images will be compelling to audiences in varying cultural, economic, and moral contexts. An analysis of the cycles of contention for and against the hunt cannot predict who will prevail, but rather reveals the changing influence and tactics of activists, and the role of movements and countermovements in changing public perception and government action through image politics.

\section{Conclusion}

Over the past six decades, the anti-sealing movement and pro-sealing countermovement have jousted, with competing mindbombs, discourses, economic actions, and scientific evidence reflecting cycles of contention in the politics of natural resource conservation and sustainable use. The history of anti-sealing campaigns suggests that the capacity of activists to influence consumers, corporations, and governments through appeals to emotion and morality is generally less effective today than it was in the past. No doubt some emotional and moral appeals still retain considerable power, and the EU and Russian bans indicate some of this continued influence. However, in a context of conflicting rights discourses (Wenzel 1991), including competing animal and cultural rights, and of contestation over the meanings and referents of words and images, from livelihood protection to cuddly babies, there is increasing competition for control over the content of emotional and ethical campaigns. Countermovement actors are inserting competing mindbombs of right and wrong into an increasingly crowded field of image politics.

In - and beyond - the case of seals, image politics itself is becoming more complex and volatile for activists. For the environmental movement this suggests a future of increasing internal fragmentation, more organised and media-savvy opposition, a more challenging media environment, and a more diverse and image-desensitised audience. The anti-sealing movement seems unlikely to achieve an outright or lasting victory anytime soon; but, it will also likely continue through a process of cycles of contention to affect consumer preferences, influence legal regulations, and disrupt market prices for seal products.

Four specific findings support this conclusion, and point to broader patterns in environmental debates. First, within anti-sealing movements, the main activist groups have changed tactics as sealing has become one of many issues, and less important to overall strategy. There are more battles within groups about goals and strategies, particularly as organisations grow. Coordination among these diverse organisations is therefore harder. Second, alongside increasing challenges within anti-sealing groups, pro-sealing groups have become more coordinated and strategic, creating more effective countermovements. Activist discourses of cruelty and endangered species are now challenged by claims of a highly regulated, humane, and sustainable hunt; seal hunters, the Canadian and Newfoundland governments, and Inuit communities have also developed more overlapping and reinforcing messages. Third, the effectiveness of mindbomb campaigns is a product not only of campaigners and countercampaigners, but also of the medium through which they are conveyed. Activists face increasing competition for media space, as proliferating NGOs and issues vie for limited media attention. Additionally, activists must engage in more radical action to gain media attention, as the demands for novel sensationalism grow.

Finally, consumers and the public are changing, as people become more accustomed to graphic images of environmental and animal rights issues, and as products reach new markets. Audiences for these campaigns, who were previously swayed by emotional appeals, are developing a fatigue of perceived moral superiority and an immunity to the images from 
traditional activist mindbombs. The main changes in campaign audiences, however, are not from the increasing cynicism of past consumers, but from the globalisation of seal markets, particularly into China, where (so far) the mindbombs once so effective in Europe have had little sway. Together, these findings suggest that as campaigners and counter-campaigners continue to articulate scientific and moral frames that resonate differently across changing cultural and media contexts, it will become increasingly difficult for activists to predict the global uptake of environmental and animal rights messaging.

\section{Acknowledgements}

The authors are grateful for funding support from the Social Sciences and Humanities Research Council of Canada as well as the exceptionally helpful feedback from the three anonymous reviewers for Environmental Politics.

\section{References}

Allen, J., 1979. Anti sealing as an industry. Journal of Political Economy. 87 (2), 423-428.

Anon., 1984. Ottawa rejects ban on seal hunt. New York Times, 10 March, 2.

Armstrong, J., 2006. Ottawa raises quota for seal hunt. The Globe and Mail, 16 March, p. A8.

Barry. D., 2005. Icy battle ground: Canada, the International Fund for Animal Welfare, and the seal hunt. St. John's, Canada: Breakwater Books.

Birkland, T.A., 2005. An introduction to the policy process: Theories, concepts, and models of public policy making, 2nd ed. Armonk, NY: M.E. Sharpe, Inc.

Bondaroff, T.P., 2008. Throwing a wrench into things: The strategy of radical environmentalism. Journal of Military and Strategic Studies, 10 (4), 1-23.

Candow, J. E., 1989. Of men and seals: a history of the Newfoundland seal hunt. Ottawa: Environment Canada.

Carragee, K.M. and W. Roefs, 2004. The neglect of power in recent framing research. Journal of Communication, 54 (2), 214-233.

Clark, C., 2010. Facing backlash in Europe, Canada hunts for new seal market in China. The Globe and Mail, 12 January.

Coish, C. E., 1979. Season of the seal: The international storm over Canada's seal hunt. St. John's, NFLD: Breakwater.

Dale, S., 1996. McLuhan's children: the Greenpeace message and the media. Toronto: Between the Lines.

Davies, B., 1989. Red ice: My fight to save the seals. London: Methuen.

DeLuca, K.M., 1999. Image politics: The new rhetoric of environmental activism. New York: The Guilford Press.

Epstein, C., 2008. The power of words in international relations: birth of an anti-whaling discourse. Cambridge, MA: MIT Press.

Fisheries and Oceans Canada, 2003. Atlantic seal hunt 2003-2005: Management plan. Ottawa: Fisheries and Oceans Canada.

Fisheries and Oceans Canada, 2004. The harp seal. Ottawa: Fisheries and Oceans Canada.

Fisheries and Oceans Canada, 2010. Overview of the Atlantic seal hunt 2006 - 2010. Ottawa: Fisheries and Oceans Canada.

Friedman, V., 2003. Fur in a not-so-cold climate: after such a loud campaign against it, why is fur making a comeback? Financial Times, 13 December, p. 5.

Goar, C., 1982. Seal Wars: The final battle? Maclean's, 6 December, 23-25. 
Harter, J-H., 2004. Environmental justice for whom? Class, new social movements, and the environment: a case study of Greenpeace Canada, 1971-2000. Labour/Le Travail, 54 (Fall), 83-121.

Horwood, H., 1960. Tragedy on the whelping ice. Canadian Audubon, 22 (2), 37-41.

Joyce, R., 1982. More than one way to skin a seal hunt. Maclean's, 95, no. 12, 22 March, 23-24.

Kean, A., 1935. Old and young ahead. Halifax: Nimbus Publishing.

Lavigne, D. M., 1995. Seals and fisheries, science and politics. Conference Paper, $11^{\text {th }}$ Biennial Conference on the Biology of Marine Mammals, 14-18 December, Orlando, Florida. Lee, J. A., 1988. Seals, wolves and words: loaded language in environmental controversy. Alternatives, 15 (4), 20-29.

Lynge, F. 1992. Arctic Wars, Animal Rights, Endangered Peoples. (translated by M. Stenbaek). Hanover, NH: University Press of New London.

McKiernan, M., 2009. Russia's seal-hunt ban pushes Canada further into isolation. The National Post, 18 March.

Moore, O., 2008. EU proposal takes aim at 'cruel' seal hunts. Globe and Mail, 24 July, p. A7.

Murphy, S. P., 2004. In Hyannis, a quiet force. Boston Globe, 15 August.

Royal Commission on Seals and the Sealing Industry in Canada, 1986. Volume 2. Seals and sealing in Canada: Report of the Royal Commission. Montreal: Royal Commission on Seals and the Sealing Industry in Canada.

Snow, D.A., E.B. Rochford, S.K. Worden, and R.D. Benford, 1986. Frame alignment processes, micromobilization, and movement participation. American Sociological Review, 51 (4), 464481.

Tarrow, S., 1998. Power in movement: Social movements and contentious politics, 2 nd ed. Cambridge: Cambridge University Press.

Tilly, C., 2004. Social movements, 1768-2004. Boulder, CO: Paradigm Publishers.

Tilly, C. and S. Tarrow, 2006. Contentious politics. Boulder, CO: Paradigm Publishers.

Vaughan, A., 2010. Record low seal catch forecast as markets dry up. Globe and Mail, 8 April, p. A5.

Weyler, R., 2004. Greenpeace: how a group of ecologists, journalists and visionaries changed the world. Vancouver: Raincoast Books.

Wenzel, G.W., 1991. Animal rights, human rights: ecology, economy, and ideology in the Canadian Arctic. Toronto: University of Toronto Press. 